http://dx.doi.org/10.12775/szhf.2020.011

\author{
Natalia Danilkina
}

Immanuel Kant Baltic Federal University, Kaliningrad, Russian Federation

E-MAIL: NATALIA.DANILKINA@YAHOO.COM

ORCID: 0000-0003-3954-3806

\title{
Immanuel Kant and the Pragmatic Turn of Science Through the Prism of Sergei Bulgakov's Metaphysics
}

In 1925, giving his lectures at the University of Marburg, Martin Heidegger mentioned two distinctive features of the philosophical renewal, which took place in the second half of the $19^{\text {th }}$ century. First of them was a "tendency to grant the particular sciences their independent right and at the same time to secure for philosophy its own field in relation to these sciences". ${ }^{1}$ This led to the transformation of philosophy itself into a theory of science or a logic of the sciences. The second feature was a turn back to a "historically established philosophy, that of Kant".

In Russia, similar traits were observed by Sergei Bulgakov at the turn of the $20^{\text {th }}$ century. In 1912, he metaphorically called the philosophical criticism the "Chinese dragon" standing in splendour on the portal of philosophical

${ }^{1}$ Martin Heidegger, History of the concept of time. Prolegomena to the Phenomenology of History and Nature, transl. Theodore Kisiel (Bloomington and Indianapolis: Indiana University Press, 1992), 13.

2 Ibidem. 
academia. ${ }^{3}$ In "The Philosophy of Economics", Bulgakov entered a dispute with his critical interlocutors Hermann Cohen, Paul Natorp, Heinrich Rickert and Immanuel Kant. Contrary to the tendency to formalise philosophy, he advanced a metaphysical view on both, philosophy and science.

\section{The Pragmatic World of Science}

An offensive of relativism in the early $20^{\text {th }}$ century provokes Bulgakov's reflection on the nature of science. The discussion opens with the issues of the scientific pluralism and conventionalism. Each science, Bulgakov notes, provides a conventional image of the world and its own reality that may be close to or far from the others. It creates its own universe, its conceptual system and its style. All this serves a particular purpose and pragmatic orientation, ${ }^{4}$ but a prism of a particular science does not provide anyone with an image of concrete life.

The single united Truth is no longer the objective of the single united Science. The concrete living material is divided in discursive knowledge, and the possibilities to bring those pieces together are very much limited. On the contrary, sciences develop in the direction of further specialisation, and contemporary pragmatism progresses in promoting the instrumental character of particular scientific truths.

All attempts to suggest an exhaustive classification of sciences, Bulgakov assumes, are the result of the quest for the unity. A plausible basis for the

${ }^{3}$ Sergiy Bulgakov, Filosofiya hozyaystva. Part 1. The World in Terms of Economics (Upper Saddle River: Gregg International Publishers Ltd., 1971), 33.

${ }^{4}$ The notion of "orientation" is frequently used by Bulgakov and is apparently borrowed from Henry Bergson. In a footnote 1, page 170, Bulgakov refers to the concept of multifaceted orientation of cognition, quoting from the 1911 Russian translation of Bergson's "Introduction to Metaphysics" (1903). The concept of pragmatic orientation was further developed by the French philosopher of life in 1907 "Creative Evolution". Both concepts originally showed the limits of intelligence's access to reality. Bulgakov speaks of "orientation" as an "arbitrary concentration on one or another point or 'fact' of life". Sergei Bulgakov, Philosophy of Economy. The World as Household, transl., ed. and with introduction by Catherine Evtuhov (New Heaven and London: Yale University Press, 2000), 56. 
hierarchical unity of sciences could be the utility of particular truths they find. In this case, however, the tree of sciences splits from the very beginning: the logical-mathematical sciences are divorced from humanities, which, again, does not bring science to the unity. The concentric schema does not suit either, since there is no single centre for science: "in a word, a labyrinth rather than concentric circles".

Neo-Kantianism and phenomenology, Bulgakov notes, confined themselves with the formal unity of science. They tried to group the disciplines depending on method. Their projects of scientific philosophy were, correspondingly, pan-methodological. Cohen and Natorp, and to some extent Rickert, Windelband, Lask and Husserl "broadened and deepened the channel made by Kant in his 'Critique of Pure Reason', which Cohen rightly characterises as a critique of pure science...".

The Marburg School of Neo-Kantianism subdued science to logics and epistemology. Paul Natorp, in his reflections on the method of exact natural sciences, following Hermann Cohen's line of thought, argued that some abstract generalisations of natural sciences (e.g., the law of conservation of energy) were merely formal constructions, on which physics was built, and their truth was asserted by their epistemic utility. ${ }^{7}$ Such claims could be easily

${ }^{5}$ Bulgakov, Filosofiya, 162-163. Translations are mine, unless noted otherwise. The English edition by Catherine Evtuhov was consulted. The original version is preferred due to more details it provides for close reading.

${ }^{6}$ Ibidem, 168. Bulgakov refers to Cohen's "Kants Theorie der Erfahrung" (Berlin: Dümmler, 1885) and "Das Prinzip der Infinitesimal-Methode and seine Geschichte" (Berlin: Dümmler, 1883).

${ }^{7}$ This is Bulgakov's reading of Natorp's reflections on mathematics and physics. Natorp, in turn, in order to support his argument on the necessity of relativism for rigorous scientific research, refers to Eduard von Hartmann's "Kategorienlehre": "Exact' validity exists only for conditional sentences, not for statements about absolute realities. Energy laws, like all other 'laws of nature', have always been conditionally pronounced by exact research, always referring to the abstraction of the 'free system'; the application to an empirically given system can never be 'exact', because empirically there cannot exist an absolutely free system. The application to the 'world' is forbidden a potiori, since the world as a closed energy system is not 'given' in any limited sense." Paul Natorp, Die logischen Grundlagen der exakten Wissenschaften (Leipzig: Teubner, 1910), 391. 
interpreted in the spirit of Henry Poincaré, whose conventionalism contributed to making him one of the co-discoverers of special relativity theory ${ }^{8}$

In mathematics, the question whether Euclidean geometry was true or not, became nonsensical as soon as other geometries were discovered. "One geometry cannot be truer than another, it can only be more convenient," quoting from "Science and Hypothesis" (1902), Bulgakov seems to accept Poincarés radical scientific pragmatism as fully corresponding to the state of affairs. Every particular truth, he admits, has its particular utility.

In the same vein, Bulgakov considers Heinrich Rickert's theory of building of concepts in natural and historical sciences to be a pragmatic theory. ${ }^{9}$ For epistemology, he argues, it does not make much sense to divide sciences into two groups, namely, natural and historical sciences, on the basis of their method. In his opinion, generalising and individualising methods pertain to both groups alike. However, being useless for epistemological teleology, this classification appears to be fruitful for the concept of teleology of culture, developed by the South-West School of Neo-Kantianism.

The "idealist" analysis of cognition, according to Bulgakov, dealt a crashing blow to positivism. "The critique of scientific reason showed with full clarity not just that sciences were built, but also how they were built". ${ }^{10}$ At the same time, Bulgakov argues, epistemological transcendentalism of Kant, and even that of neo-Kantians, despite the absolutism of their formal theories (and, perhaps, opposite to their intention - N.D.), underscored the instrumental, orientational and conventional character of science. From this point of view, "gnoseological idealism" collaborated with "positivistic pragmatism,"11

${ }^{8}$ Bernard d'Espagnat, On Physics and Philosophy (Princeton and Oxford: Princeton University Press, 2013), 370.

${ }^{9}$ Heinrich Rickert, Die Grenzen der naturwissenschaftlichen Begriffsbildung: eine logische Einleitung in die historischen Wissenschaften (Tübingen, Leipzig: Mohr, 1902).

${ }^{10}$ Bulgakov, Filosofiya, 169.

${ }^{11}$ Bulgakov's terminology is typical for the early $20^{\text {th }}$ century. To extend the context, see, for instance, Lovejoy - Montague discussion in The Journal of Philosophy, Psychology and Scientific Methods. Lovejoy considers pragmatism as "a historic complex of mixed philosophical motives and tendencies" and seeks to find a combination of its essential features. In his view, those are nominalism (positivism) and instrumentalism. See: Arthur O. Lovejoy, "Pragmatism and Realism”, The Journal of Philosophy, Psychology and Scientific Method VI (1909): 575-580. 
in spite of different philosophical premises - this Bulgakov considers a striking fact of the philosophical consciousness of his time.

Given this, Bulgakov claims Kant to be the "father of scientific pragmatism", whereas neo-Kantians Cohen, Natorp and Rickert - its prominent representatives, along with Henry Bergson and American pragmatists. ${ }^{12}$ The pragmatic turn in the history of science, according to Bulgakov, was a turn to the human nature of science.

\section{Humanity as the Transcendental Subject of Science}

Let us follow Bulgakov's argument. Ubiquitous pragmatism affirms that science is anthropoligised. When the formal epistemological idealism of neoKantians seeks for purity and opposes itself to "psychologism", it underscores the role of human factor in knowledge. They may consider science formal, but this does not prevent it from having a pragmatic, i.e. human purpose, since it is done by humans. Philosophy of science, in this sense, is a philosophy of human being. "Science is an attribute of humankind, a tool she creates for certain tasks. Science is throughout anthropological... Philosophy of science is a section of philosophical anthropology". ${ }^{13}$

According to Bulgakov, the pragmatic character of science implies that science is imbedded in a concrete contextual setting of human existence and the morphology of human body. This is why scientific views and epistemic claims appear to be the views and claims of Plato's prisoners in a cave. If the "prisoners" slightly change their positions in the "cave", Bulgakov notes, their picture of the world and things whose shadows they observe may change drastically; furthermore, if knowers were flying beings, or lived in water, or if they became microscopic or two-dimensional, etc. - all these changes would affect knowledge. ${ }^{14}$ The context- and knower-dependence suggests some doubts concerning the reality of a thing being cognised.

${ }^{12}$ Bulgakov, Filosofiya, 169-170.

${ }^{13}$ Ibidem, 178-179.

${ }^{14}$ This is Bulgakov's interpretation of the famous passage from Plato's The Republic. Cf. Bulgakov, Filosofiya, 172. 
In Bulgakov's opinion, neo-Kantians amplified the gap between the living reality and the construed reality of science. Does Cohen's science of pure logic, he asks, constitute the real being or a mere set of shadows implying the necessarily existing things? Is reality a Cohen's logical and mathematical "differential" or is it something "given" in the "raw" condition? What is more real: my impression from music and colours or relevant formulas of sound waves and light waves?

Bulgakov seeks to secure a place for the real in his philosophy. He believes that the path to reality is pre-reflective. Therefore, the key to the abovementioned questions can only be provided by what is called naive realism. ${ }^{15}$ Only life in its immediacy can be real and this living reality is not affected by knowledge.

Life is always naive, as all wholeness and immediacy is naive. Scientific, contingent, reflective reality always has meaning only in a particular interpretation, in a particular context. Even were science to succeed in understanding the entire universe as a mechanism moving with clocklike regularity, even were science, with its contingent orienting constructions, to find such a construction most convenient, life in its majestic immediacy would be just as little threatened as a landscape, which does not become less colorful and lovely from being subjected to topographical surveys and depicted on maps. ${ }^{16}$

For Bulgakov, life is a basic all-embracing notion that cannot be given an exhaustive definition, even if it is given a particular meaning such as "being" or some facet of being: will, thinking, instinct, consciousness, the subconscious sphere, etc. ${ }^{17}$ The metaphysics of the concrete real (metafizika suschego) "has in front of it being (life) as the unity in its most general and abstract definitions, in its universal connectivity and contingency..." ${ }^{18}$ Such metaphysics, or general philosophy, according to Bulgakov, were pursued by Plotinus and

${ }^{15}$ Versions of naïve realism were popular amongst the early 20th-century philosophers of perception and got a second wind in the beginning of the $21^{\text {st }}$ century. See: Anil Gomes, "Kant on Perception: Naive Realism, Non-Conceptualism, and the B-Deduction". Philosophical Quarterly 64 (2014): 1-19.

${ }^{16}$ Bulgakov, Philosophy, 162-163.

${ }^{17}$ Ibidem, 10.

${ }^{18}$ Ibidem, 24-25. 
Hegel, although the latter overestimated the role of a system. The concepts of discursive thinking, Bulgakov maintains, cannot express the concrete real and fully encapsulate it in a consistent system.

After close reading of his later works "Unfading Light" and "The Tragedy of Philosophy", one can assume, that the concept of "life" belongs to a sort of concepts that enable metaphysicians to describe and narrate their intuitions, rather than to build a system (although many of them were entrained by what Bulgakov called the "pathos of system"). Importantly, Bulgakov insists that his philosophy has its own motives and is oriented in a certain way, alike any other philosophy. Even if tends to systematicity, it does not pretend to build the absolute system. In the "Philosophy of Economy", he identifies a philosophical system with a piece of art, which requires some space for creative freedom of an artist. The aesthetic relativism ensues from the connection between philosophy and life, which holds true to sciences.

"Sciences are born of life", Bulgakov claims. ${ }^{19}$ Thought and knowledge reside in living consciousness. Each act of knowledge is an act of life and, therefore, has an immediate, pre-reflective nature. Even the "Critique of Pure Reason" developed from an idea born in Kant's living mind, Bulgakov assumes, although the theory applies the method of abstraction and dissection to the living knowledge. ${ }^{20}$

Life, Bulgakov believes, "seeps" into every philosophical system. Ultimately, at the "bottom" of Kant's Erfahrung, there lies Empfindung, which is hard to explain consistently within the system, for it transcends the system. ${ }^{21}$ It refers to the concrete experiencing of life that is not transcendent to the concrete living being but remains transcendent as Kant's Ding an sich to the reflecting knowing subject.

${ }^{19}$ Ibidem, 178.

${ }^{20}$ In this statement, Bulgakov agrees with the sharp critique of the method of Kant's epistemology presented in the first part of Die Logik auf dem Scheidewege (1903) by Melchior Palágyi (Bulgakov, Filosofiya, 34). In the claims of Albert Einstein's opponents, Palágyi’s natural philosophy was given the priority for the discovery of the link between time and space. See: Milena Wazeck, Einstein's Opponents: The Public Controversy about the Theory of Relativity in the 1920s, transl. Geoffrey S. Koby (Cambridge: Cambridge University Press, 2014), 165.

${ }^{21}$ Kant's "feeling of existence" and his notion of Empfindung were recently revisited, i.a., in: Apaar Kumar, "Transcendental Self and the Feeling of Existence", CON-TEXTOS KANTIANOS. International Journal of Philosophy 3 (2016): 90-121. 
Bulgakov's knowing subject and Kant's transcendental subject do not coincide. The central idea of Kant's epistemology, Bulgakov writes, is the universal validity (Allgemeingültigkeit) of knowledge. The universally valid knowledge is possible and understandable provided there is the universal transcendental subject. However, Kant's transcendental subject of knowledge does not exist. It does not pertain to the living and embodied $I$, but to a skeleton of the epistemic forms.

The gnoseological subject, representing in Neo-Kantianism the center the world revolves around (this is the notorious "Copernicanism" of Kant), is something that exists neither in experiential reality, for the latter is concrete and psychological, that is, not "pure"; nor outside this experience, beyond the limits, in the transcendent, for entry is fundamentally forbidden there. Hence, the epistemological individual is merely a methodological fiction, nothing but a method (as proclaimed by Cohenianism), whereas knowledge is left without a real subject, its genuine carrier. ${ }^{22}$

The knower, according to Bulgakov, cannot be a mere idea or a method. She must have being in itself. The genuine subject of knowledge is the subject of undivided life. It is the metaphysical unity of all human beings that were ever born and will be born, the "man" in the universal and historical meaning of the word, humanity (chelovechestvo). It is not impossible in principle, Bulgakov says, that a person of ingenious mind and tremendous capacity for work would carry in herself all the knowledge of humanity. This possibility, however, is constrained by the limits of human life, energy, and health. Therefore, although there is the one, who knows, there are many, who struggle to know.

Thus, "the transcendental subject is no longer a human individual, but the whole humanity". ${ }^{23}$ The unified transcendental subject, Bulgakov notes, has different names in the history of thought - the World's Soul, Pleroma, Divine Sophia, or Natura Naturans generally understood as the organism of living ideas (Bulgakov). The unity was discussed in Ancient Greece, Neo-Platonism and Christian thought (St. Dionysius the Areopagite, St. Maximus the Confes-

\footnotetext{
${ }^{22}$ Bulgakov, Filosofiya, 116.

${ }^{23}$ Ibidem, 119.
} 
sor, St. Gregory of Nyssa). It was revived in what we call now the philosophy of modernity, which was not devoid of mysticism. In modern German philosophy, Bulgakov especially praises Schelling, whose natural philosophy acknowledged that nature was the living organism. In Russia, the image of Divine Sophia appeared in philosophical and poetic writings of Vladimir Solovyov. Later on, sophiological teachings were developed by a few influential thinkers, albeit those ideas were not shared by the Orthodox clergy.

All acts of knowledge exist as the activity and energy of the unified living subject, Bulgakov claims. Otherwise, neither tradition as the transmission of knowledge, nor scientific progress would be possible. The unity of form (universal norms, logical laws, epistemic categories, etc.), as well as the unity of matter, are equally justified by this single subject of knowledge.

All features Kant identified as a priori of knowledge, Bulgakov continues, pertain to this subject, who relates the variety of experience to the single space and aligns it along the line of the single time, makes connections within it by means of causality. Furthermore, not only a priori forms of knowledge, but also its a posteriori matters, i.e. the entire content of knowledge drawn together under the assumption of the a priori forms, should be attributed to this subject. "The unity of the subject of knowledge from the side of a priori necessarily leads to the extrapolation of this unity on its a posteriori as well, although for the separate human consciousnesses this unity is only formal and potential as the possibility of the acquisition of knowledge at all”. ${ }^{24}$

Bulgakov retains the potentiality-actuality dichotomy. His transcendental subject of integral knowledge is conceived as the potential. Although Sophia can be interpreted as a sort of Platonic "idea" (Vladimir Solovyov called her "an ideal humanity"), Bulgakov's actualising Sophia is also close to "Aristotelian entelechy with respect to the potential state of being." ${ }^{25}$ Following Aristotle, Bulgakov seeks to escape the world's dualism. Sophia does not make a separate world, he argues. The claim that the world is sophic means that the potential is actualised in history, in the course of time, whereas its ideal precondition lies beyond history and is supratemporal. The ideal is separated

\footnotetext{
${ }^{24}$ Ibidem, 118.

${ }^{25}$ Sergei N. Bulgakov, Svet nevecherniy: Sozertsaniya i umozreniya (Moscow: Respublika, 1994), 194.
} 
from this world only if the world is abstractly taken in a particular moment of time, when it represents, so to say, the potential that is not being actualised. This lifeless situation is commonly encountered in the form of scientific constructions.

Scientific "truth" is a process and never a fixed result. The final result cannot be found on the timeline of history. The universal knowledge is never actualised in full; "all knowable truths are multiple and contingent, in accordance with the discursiveness of knowledge". ${ }^{26}$ Nonetheless, the "truths" of knowledge presuppose the single Truth as being, which exists as an aspiration in every individual consciousness. In a cognitive act of a particular individual, knowledge transcends from its potentiality to the actual status of being and is further organised in a way revealing its endeavour to the unity.

From the perspective of Kant's transcendental philosophy, the view of the whole humanity that Bulgakov describes through his "mystical intuition" of Sophia lies beyond human capacity of understanding. Knowledge of such totalities is not authorised even on the borders of the epistemic domain:

But since a boundary is itself something positive, which belongs as much to what is within it as to the space lying outside a given totality, reason therefore, merely by expanding up to this boundary, partakes of a real, positive cognition, provided that it does not try to go out beyond the boundary, since there it finds an empty space before it, in which it can indeed think the forms for things, but no things themselves. ${ }^{27}$

Kant's epistemological restrictions were adopted and reinterpreted by neoKantians and other followers of critical philosophy, who completely rejected metaphysics in their theories of knowledge. These philosophies focused on the formal aspects of knowledge and claimed themselves scientific. Preserving Kant's unity of science as the "idea", they could only propose formal classifications of sciences on a strictly methodological basis.

\footnotetext{
${ }^{26}$ Bulgakov, Filosofiya, 126.

${ }^{27}$ Immanuel Kant, Prolegomena to Any Future Metaphysics That Will Be Able to Come Forward as Science: With Selections from the Critique of Pure Reason, transl. and ed. Gary Hatfield (Cambridge: Cambridge University Press, 2004), 4: 361.
} 


\section{Conclusion}

Thus, we may conclude that Bulgakov was not convinced with Kant's words concerning the self-sufficiency of pure reason for metaphysics:

I make bold to say that there cannot be a single metaphysical problem that has not been solved here, or at least to the solution of which the key has not been provided. In fact pure reason is such a perfect unity (vollkommene Einheit) that if its principle were insufficient for even a single one of the questions that are set for it by its own nature, then this [principle] might as well be discarded, then it also would not be up to answering to any of the other questions with complete reliability. ${ }^{28}$

Although Kant's name was central to the quest of the unity of science in the beginning of the $20^{\text {th }}$ century, Bulgakov considered the unity envisioned by Kant to be an ideal, which was useful only for formal constructions and construing. The crucial thesis of Bulgakov's argument could be formulated as follows: the universal ground for scientific research cannot be just formal, for the universe is not void. In terms of Bulgakov's metaphysics, the unity of science is grounded, firstly, in the real life as its immediate "substratum". Secondly, it is embedded in the unity of the transcendental subject conceived as living humanity, which Kant abandoned in his theory of knowledge. If Kant made a right turn, this was a turn towards the human nature of science, i.e., towards scientific pragmatism.

Our knowledge depends on a given setting and on the initial position taken arbitrarily by researchers. This explains relativism and conventionalism in science. At the same time, science is "anchored" in human body. The anthropomorphism, according to Bulgakov, appears to be the main key to the universality.

Here we find a significant difference between Bulgakov's religious realism and contemporary speculative realism. The speculative realism stays aloof from anthropocentrism and anthropomorphism; instead, it takes

${ }^{28}$ Immanuel Kant, Critique of Pure Reason, transl. and eds. Paul Guyer and Allen Wood (Cambridge: Cambridge University Press, 1998), Axiii. 
contingency itself, which is claimed to be the ground of all relativisms, for the universal starting point to all ontology (Saldanha, 2009; 311). For Bulgakov, such dehumanisation is impermissible. It would be a crime against ontology and another attempt (after "Copernicus" Kant) to hammer a nail into the air in order to support the entire universe. ${ }^{29}$

Unlike neo-Kantians, who aggravated Kant's "sin" consisting in the atomisation of the living humanity in his epistemology, Bulgakov seeks to correct it suggesting a sophic vision of science. The idea of actualising Sophia, which is the single universal subject encompassing all human beings, explains why there are no subjects of knowledge that are fully isolated from each other like transcendent epistemological worlds.

The unity of knowledge implies its ultimate completeness that is regarded as potentially attainable in one transcendental subject. This makes the transmission of knowledge and advancement in science possible and drives the inner organisation and systematisation of the multitude of sciences.

\section{References}

Bulgakov Sergei N. 1994 [1917]. Svet nevecherniy: Sozertsaniya i umozreniya. [Unfading Light: Contemplations and Speculations]. Moscow: Respublika.

Bulgakov Sergei. 2000 [1912]. Philosophy of Economy. The World as Household, transl., ed. and with introduction by Catherine Evtuhov. New Heaven and London: Yale University Press.

Bulgakov Sergej N. 1927 [1920]. Die Tragödie der Philosophie. Darmstadt: Otto Reichl Verlag.

Bulgakov Sergiy. 1971 [1912]. Filosofiya hozyaystva [The Philosophy of Economics]. Part 1. The World in Terms of Economics. Upper Saddle River: Gregg International Publishers Ltd.

Cohen Hermann. 1883 [1876]. Das Prinzip der Infinitesimal-Methode und seine Geschichte: ein Kapitel zur Grundlegung der Erkenntniskritik. Berlin: Dümmler.

Cohen Hermann. 1885 [1871]. Kants Theorie der Erfahrung. Berlin: Dümmler.

d'Espagnat Bernard. 2013. On Physics and Philosophy. Princeton and Oxford: Princeton University Press.

${ }^{29}$ Bulgakov, Philosophy, 128. 
Gomes Anil. 2014. "Kant on Perception: Naive Realism, Non-Conceptualism, and the B-Deduction". Philosophical Quarterly 64, 254: 1-19.

Heidegger Martin. 1992. History of the concept of time. Prolegomena to the Phenomenology of History and Nature. Transl. Theodore Kisiel. Bloomington and Indianapolis: Indiana University Press.

Kant Immanuel. 1998. Critique of Pure Reason. Transl. and eds. Paul Guyer and Allen Wood. Cambridge: Cambridge University Press.

Kant Immanuel. 2004. Prolegomena to Any Future Metaphysics That Will Be Able to Come Forward as Science: With Selections from the Critique of Pure Reason. Transl. and ed. Gary Hatfield. Cambridge: Cambridge University Press.

Kumar Apaar. 2016. "Transcendental Self and the Feeling of Existence". Con-textos Kantianos. International Journal of Philosophy 3: 90-121.

Lovejoy Arthur O. 1909. "Pragmatism and Realism". The Journal of Philosophy, Psychology and Scientific Method VI: 575-580.

Natorp Paul. 1910. Die logischen Grundlagen der exakten Wissenschaften. Leipzig: Teubner.

Palágyi Melchior. 2010 [1903]. Die Logik auf dem Scheidewege. Whitefish: Kessinger Publishing.

Plato. 2006. The Republic. Transl. R. E. Allen. New Haven: Yale University Press.

Poincaré Henri. 1902. La science et l'hypothèse. Paris: Ernest Flammarion.

Rickert Heinrich. 1902. Die Grenzen der naturwissenschaftlichen Begriffsbildung: eine logische Einleitung in die historischen Wissenschaften. Tübingen, Leipzig: J.C.B. Mohr (Paul Siebeck).

Saldanha Arun. 2009. "Back to the Great Outdoors: Speculative Realism as Philosophy of Science". Cosmos and History: The Journal of Natural and Social Philosophy 5, 2: 304-321.

Wazeck Milena. 2014. Einstein's Opponents: The Public Controversy about the Theory of Relativity in the 1920s. Transl. Geoffrey S. Koby. Cambridge: Cambridge University Press.

\begin{abstract}
In the early $20^{\text {th }}$ century, science reveals its instrumental and conventional character. These pragmatic features, according to Sergei Bulgakov, underscore the dependence of scientific claims on human qualities and purposes. Science is anthropologised; therefore, philosophy of science can be regarded as a part of philosophical anthropology. The pragmatic turn of science, Bulgakov argues, had a Kantian impulse. In 1912 book "Philosophy of Economy", Bulgakov advances a metaphysical view on science in a dispute with his critical interlocutors - Hermann
\end{abstract}


Cohen, Paul Natorp, Heinrich Rickert, and their prominent predecessor Immanuel Kant. This paper shows that despite a fundamental disagreement concerning the notion of the transcendental subject, Bulgakov does not disprove the utility of Kant's transcendental theory of knowledge. He rather points out the limits of this theory (Kant primarily insisted on) and overrides those limits as dispensable for philosophy, which does not have to be a formal science.

Keywords: unity of science, relativism, conventionalism, Russian religious thought, Sophia, humanity, transcendental subject 